\title{
CLINICAL, BIOCHEMICAL AND VIROLOGICAL PROFILE OF PATIENTS WITH CHRONIC HEPATITIS C VIRUS INFECTION-A STUDY FROM UNIVERSITY HOSPITAL IN NEPAL
}

\author{
Dipesh Gurubacharya, Mohan Khadka, Khadga B. Shrestha, \\ Prem Khadga, Sashi Sharma
}

\begin{abstract}
Introduction: Hepatitis $\mathrm{C}$ virus (HCV) infection is a major public health challenge. It is a major cause for cirrhosis and hepatocellular carcinoma worldwide. Both the genotype and viral load of HCV determine the choice of therapy as well as outcome of therapy. The aim of this study was to evaluate clinical, biochemical and virological profile and association of HCV genotypes with viral load and liver biochemical profile.
\end{abstract}

Material and Methods: This was descriptive observational study of chronic HCV infected patients who attended at the outpatient clinic of Department of Gastroenterology of TUTH, IOM from April 2013 to November 2014. During this study period 38 patients with chronic $\mathrm{HCV}$ infection were analyzed. Clinical profile, possible risk factors for transmission of HCV infection and liver biochemical profile were recorded. Virological profile included HCV viral load and HCV genotypes.

Results: Out of 38 patients $34(89.5 \%)$ were male and 4(10.5\%) were female. Injection drug use (IDU) was the most common mode for acquisition of HCV infection (55.3\%). Genotype 3 was found in 21(55.26\%) patients and genotype 1 was found in $17(44.74 \%)$ patients. There was no significant association between $\mathrm{HCV}$ genotypes and serum alanine aminotransferase (ALT) and aspartate aminotransferase (AST) level. And also there was no significant association between HCV viral load and different HCV genotypes.

Conclusions: In our study HCV genotype 3 was the most prevalent genotype in patients with chronic $\mathrm{HCV}$ infection. Injection drug use was identified as most common identifiable risk factor for transmission of $\mathrm{HCV}$ infection. There was no significant association between different HCV genotypes and serum ALT, AST level and HCV viral load.

Key words: $A L T, A S T$, genotype, hepatitis $C$ virus, viral load

\section{Introduction}

Hepatitis $\mathrm{C}$ virus (HCV) infection is a major public health challenge worldwide. About 170 million people or $3 \%$ of world's population are infected with HCV. ${ }^{1}$ More than 350,000 deaths annually are attributed to HCV infection, most of which are caused by cirrhosis of liver and hepatocellular carcinoma (HCC). ${ }^{2}$ An estimated $27 \%$ of cirrhosis and $25 \%$ of $\mathrm{HCC}$ can be attributed to $\mathrm{HCV}$ worldwide. ${ }^{2}$ In developed countries,

the most important route of $\mathrm{HCV}$
transmission is intra-venous drug use, whereas in resource poor countries, invasive procedures or injection-based therapies with contaminated instruments are predominant source of new infections. ${ }^{3}$ Different studies from Nepal showed that the sero-prevalence of $\mathrm{HCV}$ ranges from $0.35 \%$ to $1.73 \%$ in blood donors and healthy population with highest prevalence among injection drug users. $^{4-8}$ Six different HCV genotypes and 
multiple subtypes have been identified on the basis of molecular relatedness. ${ }^{9}$ Knowledge of the genotype is helpful for prediction of sustained virological response (SVR) and choice of treatment duration. ${ }^{10}$ Chronic HCV infection is associated with a wide variation in serum ALT level, from normal ALT to persistent elevation of ALT. Approximately $25-30 \%$ of individuals with chronic HCV infections have persistently normal ALT level. ${ }^{11}$

The aim of this study was to determine clinical, biochemical, HCV genotype distribution and HCV viral load in patients infected with chronic HCV and to assess the relationship between $\mathrm{HCV}$ genotype with serum ALT level, serum AST level and HCV viral load.

\section{Material and Methods}

This study was a descriptive observational study of chronic HCV infected patients who attended at the outpatient clinic of Department of Gastroenterology of Tribhuvan University, Institute of Medicine (TU, IOM) from April 2013 to November 2014. All the included patients were positive for Anti-HCV by ELISA. All the patients were positive for HCV RNA by Real Time- Polymerase Chain Reaction (PCR). All the patients who were not taking anti-viral treatment for HCV infection were included in this study, but the co-infected patients with hepatitis B virus (HBV) and human immunodeficiency virus (HIV) were excluded. All the information regarding clinical profile, liver biochemical parameters and virological parameters were recorded digitally. Patient's clinical details included age, gender and possible risk factors for $\mathrm{HCV}$ transmission. Liver biochemical parameters included serum ALT and AST level. Virological profiles included HCV viral load and HCV genotypes. As $\mathrm{HCV}$ genotype and $\mathrm{HCV}$ viral load testing facility is not available in Nepal, HCV viral load and genotypes were done in different laboratories in India where RT-PCR for determining HCV viral load and genotypes were available.
The data obtained was entered in Microsoft Excel and exported to further statistical analysis was done using statistical package for social sciences (SPSS) version 20. Standard descriptive statistical analysis was carried out as per demographic, biochemical and HCV viral load. The relationship was analyzed by comparing variables using Student t-test. Results were considered significant if $p$-value was less than 0.05 .

\section{Results}

During April 2013 to November 2014 there were 38 patients of chronic $\mathrm{HCV}$ infection who attended outpatient clinic of Department of Gastroenterology at TUTH, IOM. Among all patients, 34 (89.5\%) were male and $4(10.5 \%)$ were female. The mean age of the study population was 38.34 years \pm 9.64 . The highest numbers of cases i.e. $52.6 \%$ were found in the age group between 30 to 40 years. The probable risk factors for transmission of $\mathrm{HCV}$ infection was observed to be IDU in $21(55.3 \%)$ patients, combined risk of IDU and tattooing in 8 $(21.1 \%)$, history of blood transfusion in 2 $(5.3 \%)$ patients, history of surgery in 1 (2.6\%) patient, hemodialysis in $1(2.6 \%)$ patient and only tattooing in $1(2.6 \%)$ patient. Among 4 (10.5\%) patients with chronic $\mathrm{HCV}$ infection, risk factor for $\mathrm{HCV}$ transmission could not be identified (Table 1).

Table 1. Characteristics of Patients $(n=38)$

\begin{tabular}{|l|c|c|}
\hline Characteristics & Frequency & Percentage \\
\hline Gender & 34 & 89.5 \\
$\quad$ Male & 4 & 10.5 \\
Female & 7 & \\
\hline Age (years) & 20 & 18.4 \\
$\quad<30$ & 11 & 52.6 \\
$30-40$ & & 28.9 \\
$>40$ & 21 & 55.3 \\
\hline Possible risk factors & 8 & 21.1 \\
IDU & 2 & 5.3 \\
IDU+ Tattooing & 1 & 2.6 \\
History of blood & 1 & 2.6 \\
transfusion & 1 & 2.6 \\
History of surgery & 4 & 10.5 \\
Tattooing & \\
Hemodialysis & & \\
Unidentified & & \\
\hline
\end{tabular}




\begin{tabular}{|l|c|c|}
\hline HCV genotypes & 17 & 44.74 \\
Genotype 1 & 21 & 55.26 \\
Genotype 3 & 0 & 0 \\
Other Genotypes & & \\
\hline
\end{tabular}

Mean serum ALT and AST level were 86.39 $\mathrm{IU} / \mathrm{ML} \pm 46.96$ and 76.08 IU/ML \pm 69.60 respectively. Mean $\mathrm{HCV}$ viral load was 3337815.76 IU/ML \pm 5087752.64 (Table 2).

Table 2. Biochemical and virological profile of study population $(n=38)$

\begin{tabular}{|l|l|}
\hline Variables & Results $^{\text {a }}$ \\
\hline ALT (IU/ML) & $86.39 \pm 46.96$ \\
\hline AST (IU/ML) & $76.08 \pm 69.60$ \\
\hline $\begin{array}{l}\text { HCV RNA } \\
\text { (IU/ML) }\end{array}$ & $3337815.76 \pm 5087752.64$ \\
\hline${ }^{a}$ Mean \pm SD
\end{tabular}

HCV genotype 3 was found common in 21 $(55.26 \%)$ patients and genotype 1 was found in $17(44.74 \%)$ patients. HCV genotype 2, 4, 5 and 6 was not found in our study population (Table 1). The statistical analysis showed no significant association between different $\mathrm{HCV}$ genotype with mean $\mathrm{HCV}$, viral load as well as mean serum AST and ALT level. (Table 3).

Table 3. Comparisons between HCV genotypes and serum AST, ALT and HCV RNA $(n=38)$

\begin{tabular}{|l|l|l|l|}
\hline & $\begin{array}{l}\text { Genotype 1 } \\
(\mathrm{n}=17)\end{array}$ & $\begin{array}{l}\text { Genotype 3 } \\
(\mathrm{n}=21)\end{array}$ & $\begin{array}{l}p \\
\text { value }\end{array}$ \\
\hline $\begin{array}{l}\text { ALT } \\
(\mathrm{IU} / \mathrm{ML})^{\mathrm{a}}\end{array}$ & $78.35 \pm 45.29$ & $92.90 \pm 48.36$ & 0.349 \\
\hline $\begin{array}{l}\text { AST } \\
(\mathrm{IU} / \mathrm{ML})^{\mathrm{a}}\end{array}$ & $71.12 \pm 87.72$ & $80.10 \pm 52.62$ & 0.698 \\
\hline $\begin{array}{l}\mathrm{HCV} \text { viral } \\
\text { load } \\
(\mathrm{IU} / \mathrm{ML})^{\mathrm{a}}\end{array}$ & $\begin{array}{l}3574804.82 \\
\pm 5464909.7\end{array}$ & $\begin{array}{l}3145967.48 \pm \\
7889692.57\end{array}$ & 0.800 \\
\hline
\end{tabular}

${ }^{\mathrm{a}}$ Mean \pm SD

\section{Discussion}

This study included 38 patients with chronic $\mathrm{HCV}$ infection. Among these patients $89.5 \%$ were male and $10.5 \%$ were female. Among 38 patients, 34(89.47\%) patients had identifiable risk factors for $\mathrm{HCV}$ transmission. Injection drug use was most common identifiable risk factor followed by the history of blood transfusion in our study population which was in concordance with the study conducted by Hu KQ from United States. $^{12}$ In similar studies from India conducted by R. Abraham and A. Chakravarti also showed the most common identifiable risk factor for $\mathrm{HCV}$ acquisition was history of surgery followed by blood transfusion. ${ }^{13,14}$ The mode of transmission was not identifiable in $10.5 \%$ of patients in this study population. A study from India showed that risk factors were not indentified in $22.53 \%$ of patients. $^{14}$ There was no published data on the distribution of different $\mathrm{HCV}$ genotypes among $\mathrm{HCV}$ infected patients found in Nepal. This study showed genotype $3(55.26 \%)$ as the most common genotype followed by genotype 1 (44.74\%).

The relationship between serum liver enzyme and degree of liver damage in chronic HCV infection was still not clear in this study but some studies documented. ${ }^{11,15}$ However, in some studies, there were no relation between serum ALT level and severity of liver damage histologically found. ${ }^{13,16}$ A study done by R. Abraham in India had shown that there was no association between HCV genotype and serum aminotransferases. ${ }^{13}$ However, another study done by A Chakravarti in India had shown that serum AST level was significantly higher in genotype 1 as compared to other genotype. ${ }^{14}$ A similar study done in Turkey by S. Rota had demonstrated that the serum level of ALT and AST in HCV genotype 4 were significantly higher than those infected with other genotypes. ${ }^{17}$ In this study, there was no significant association between $\mathrm{HCV}$ genotype and the mean level of serum ALT level and serum AST level was found. In a study from India conducted by R. Abraham found that serum ALT level correlated poorly with $\mathrm{HCV}$ genotype ${ }^{13,14}$. There was little information regarding the correlation between the HCV genotype and viral load found. Some studies had shown that there was no relationship between the $\mathrm{HCV}$ genotype and $\mathrm{HCV}$ viral load. ${ }^{11,18}$ A study conducted at Pakistan in 2011 showed a 
significant higher $\mathrm{HCV}$ viral load in genotype 1 as compared to other genotypes. ${ }^{19}$ A similar kind of study done in India also showed that viral load in patients with genotype 1 was significantly higher than other HCV genotypes. ${ }^{14}$ In this study, there was no significant association between HCV viral load and HCV genotypes.

\section{Conclusions}

In conclusion, this study showed that HCV genotype 3 was the most common genotype followed by genotype 1 . Other Genotypes were not found in this study population. This study also revealed that there was no significant relation between the $\mathrm{HCV}$ genotypes, serum ALT and serum AST level. Baseline HCV viral load was also not significantly associated with different $\mathrm{HCV}$ genotypes.

\section{References}

1. Lavanchy D. Evolving epidemiology of hepatitis C virus. Clin Microbiol Infect. 2011; 17:107-115.

2. Averhoff FM, Glass N, Holtzman D. Global burden of hepatitis $\mathrm{C}$ : considerations for healthcare providers in the United States. Clin Infect Dis. 2012; 55 Suppl 1: S10-5.

3. Hauri AM, Armstrong GL, Hutin YJ. The global burden of disease attributable to contaminated injections given in health care settings. Int J STD AIDS. 2004; 15:7-16.

4. Shrestha B. Serological surveillance of antiHCV antibody among Nepalese males. J Nep Health Res Council. 2006; 4: 7-11.

5. Karki S, Ghimire P, Tiwari BR, et al. Trends in hepatitis B and hepatitis C seroprevalence among Nepalese blood donors. Jpn J Infect Dis. 2008; 61: 324-326.

6. Karki S, Ghimire P, Tiwari BR, et al. Seroprevalence of anti HCV antibodies among blood donors in Kathmandu Valley, Nepal. Kathmandu Univ Med J. 2008; 6: 491-496.

7. Sawayama Y, Hayashi J, Ariyama I, et al. A ten year serological survey of hepatitis A, B and
$\mathrm{C}$ viruses infections in Nepal. J Epidemiol. 1999; 9:350-354.

8. Shrestha SM, Subedi NB, Shrestha S, et al. Epidemiology of hepatitis $\mathrm{C}$ virus infection in Nepal. Trop Gastroenterol. 1998; 19: 102-104

9. Lauer GM, Walker BD. Hepatitis C virus infection. N Engl J Med. 2001, 345:41-52.

10. Poynard T, Yuen MF, Ratziu V, et al. Viral hepatitis C. Lancet. 2003; 362: 2095-2100.

11. Lee YS, Yoon SK, Chung ES, et al. The relationship of histological activity to serum ALT, HCV genotype and HCV RNA titers in chronic hepatitis C. J Korean Med Sci. 2001; 16: 585-591.

12. Hu KQ, Yang H, Lin YC, et al. Clinical Profiles of Chronic Hepatitis $\mathrm{C}$ in a Major County Medical Center Outpatient Setting in United States. Int J Med Sci. 2004; 1: 92-100.

13. Abraham R, Ramakrishna B, Balekuduru A, et al. Clinicopathological features and genotype distribution in patients with hepatitis $\mathrm{C}$ virus chronic liver disease. Indian $\mathrm{J}$ Gastroenterol. 2009; 28: 53-58.

14. Chakravarti A. Dogra G, Verma V, et al. Distribution pattern of HCV genotypes \& its association with viral load. Indian J Med Res. 2011; 133:326-331.

15. Liu P, Li Y, Sun C. Correlations of serum hepatitis $\mathrm{C}$ virus RNA and alanine transaminase with liver histopathological changes in patients with chronic hepatitis C. Lab Med. 2009;40:167169.

16. Puoti C, Magrini A, Stati T, et al. Clinical, histological, and virological features of hepatitis $\mathrm{C}$ virus carriers with persistently normal or abnormal alanine transaminase levels. Hepatology. 1997; 26: 1393-1398.

17. Rota S, Fidan I, Lale Z, et al. Determination of hepatitis $\mathrm{C}$ virus genotype in Turkey by pyrosequencing technology and its association with viral load and SGOT, SGPT levels. Acta Medica Mediterranea. 2013; 29:397-402.

18. Adinolfi LE, Utili R, Andreana A, et al. Relationship between genotypes of hepatitis $\mathrm{C}$ virus and histopathological manifestations in chronic hepatitis C patients. Eur J Gastroenterol Hepatol. 2000; 12: 299-304.

19. Ali A, Nisar M, Ahmad H, et al. Determination of HCV genotypes and viral loads in chronic $\mathrm{HCV}$ infected patients of Hazara Pakistan. Virol J. 2011; 8: 466.

Correspondence Address: Dr Dipesh Gurubacharya, Department of Gastroenterology, Institute of Medicine, Tribhuvan University Teaching Hospital, Maharajgunj, Kathmandu, Nepal. Email: dipeshgurubacharya@gmail.com 